TITLE:

\title{
A Note on the Feeding Habit of a Calanoid Copepod, Pontellopsis yamadae Mori
}

AUTHOR(S):

Ohtsuka, Susumu

\section{CITATION:}

Ohtsuka, Susumu. A Note on the Feeding Habit of a Calanoid Copepod, Pontellopsis yamadae Mori. PUBLICATIONS OF THE SETO MARINE BIOLOGICAL LABORATORY 1985, 30(1-3): 145-149

\section{ISSUE DATE:}

1985-06-30

URL:

http://hdl.handle.net/2433/176097

RIGHT: 


\title{
A Note on the Feeding Habit of a Calanoid Copepod, Pontellopsis yamadae Mori
}

\author{
By \\ Susumu Ohtsuka ${ }^{1)}$ \\ Seto Marine Biological Laboratory, Kyoto University, Shirahama, \\ Wakayana, 649-22, Japan
}

With Text-figures $1-2$ and Table 1

In contrast to the majority of calanoid copepods, which is planktonic, such calanoids as pontellids are neustonic (e.g., Hattori et al., 1983) and their feeding habits as well as prey-predator relationships around them can be expected to be somewhat different from those of planktonic calanoids. However, our knowledge on feeding habits of neustonic calanoids is still very poor, perhaps because of difficulty in collecting enough material. In my opinion, tedious efforts to accumulate evidences which show their feeding habits are inevitable to clarify their ecological roles in complex food webs in the marine pelagos. In the present paper, along this belief of mine, I report the feeding habit of Pontellopsis yamadae Mori (Family Pontellidae) which has become apparent from observation of an adult female collected with a neuston net in the North Pacific off the Kii Peninsula, Japan.

The following observation was made on an adult female of Pontellopsis yamadae which was collected during an investigation on the neuston above a depth of $15 \mathrm{~cm}$ off Tsubaki on the western coast of the Kii Peninsula $\left(33^{\circ} 37^{\prime} \mathrm{N}, 135^{\circ} 17^{\prime} \mathrm{E}, 12-\mathrm{X}-1983\right)$ together with other pontellid copepods. The specimen, whose body was $3.02 \mathrm{~mm}$ long, was mounted onto a slide-glass with Gum-chloral medium and examined with the differential interference microscope.

Before going further, I would like to express my sincere thanks to Dr. T. Itô of Kyoto University for reading the manuscript. Thanks are also due to Dr. S. Fuse, Messrs S. Sakai and Y. Yamamoto for their cooperation at sea.

\section{The feeding habit of Pontellopsis yamadae}

The copepod was in the act of ingesting a small chaetognath as shown in Figs 1 and 2-A. Most of the posterior portion of the prey had been swallowed before the sample was fixed in formalin immediately after capture. The chaetognath was firmly grasped by the maxillulae and maxillae of the copepod. Considering the advanced stage of the ingestion of the prey, it is unlikely that the predation occurred

1) Present address: Faculty of Applied Biological Science, Hiroshima University, Fukuyama, Hiroshima, 720, Japan.

Publ. Seto Mar. Biol. Lab., 30 (1/3). 145-149, 1985

(Article 6) 


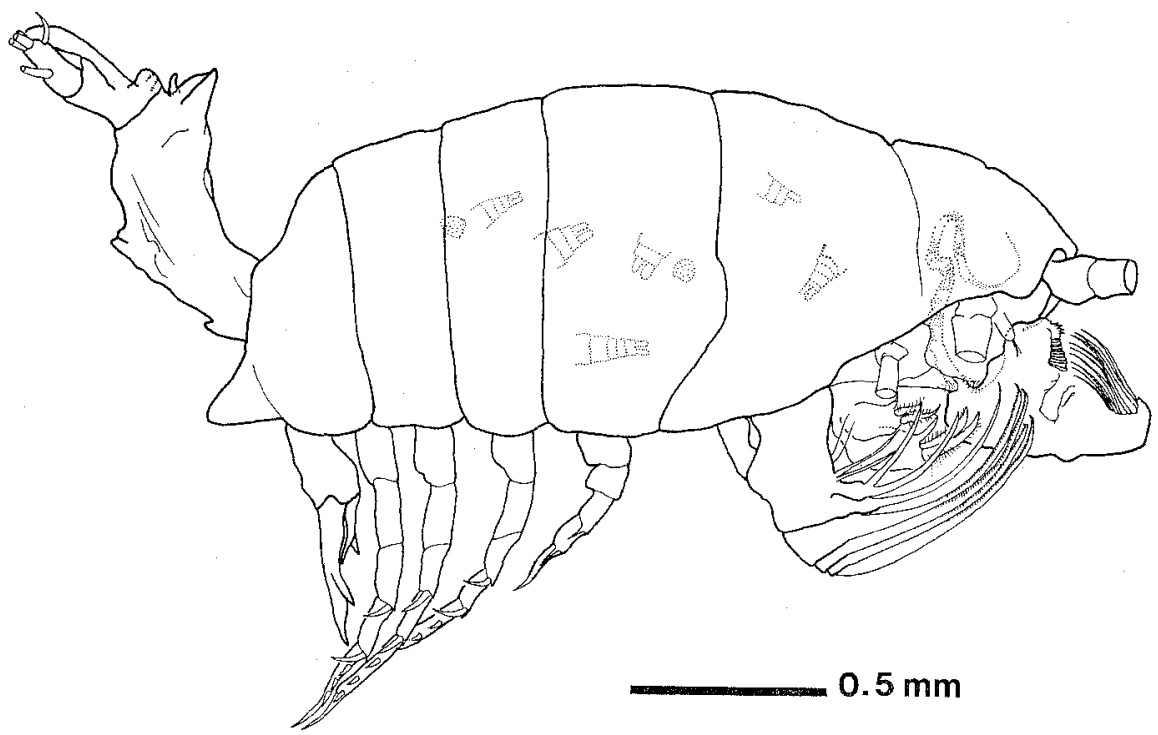

Fig. 1. Pontellopsis yamadae feeding a small chaetognath, copepods and tintinnids. Antennule, antenna and mandible of the copepod omitted.

incidentally in the cod end of the neuston net. Evidently the attack on the chaetognath must have taken place in the open water. The number of hook, anterior and posterior teeth of the chaetognath was 12,4 and 5 , respectively. The number was almost equal to those of three species of the genus Sagitta: S. bedfordii Doncaster, S. enflata Grassi, and S. regularis Aida (see Alvariño, 1967). The pontellid copepod also preyed on copepodids of the harpacticoid copepod Euterpina acutifrons (Dana) and other copepods, and tintitnnids (Figs $\mathrm{I}$ and $2-\mathrm{B}, \mathrm{G}$ ). The prey copepods were cut into pieces, but the loricae of the tintinnids were neither crushed nor chopped up. It is unlikely that these tintinnid loricae were derived from gut contents of the prey copepods, because every lorica is too large to be swallowed by these prey copepods without chewing. I suppose these tintinnids were taken by this pontellid with filtering activity of her oral appendages and swallowed up, though a possibility that they were derived from gut contents of the prey chaetognath still remains.

Table 1 shows the food items of 13 species of the family Pontellidae. These species are classified into carnivore or omnivore. Although pontellid copepods are generally regarded as typical carnivores, many species feed on phytoplankters as well as zooplankters. Pontellopsis yamadae and Labidocera acuta (Dana) (copepodid V stage) prey on predacious chaetognaths which feed on many zooplankters such as tintinnids, medusae, cladocerans, copepods, mysids, euphausiids, decapods, appendicularians, fish larvae and chaetognaths (Alvariño, 1965; Ohtsuka, unpublished). Therefore, pontellid copepods are considered to play important ecological roles as high-order predators in neustonic food webs.

Wickstead $(1959,1962)$ and Davis (1977) reported the predation of the copepods on chaetognaths. The former described the predation of the calanoid copepod Candacia bradyi Scott and two poecilostomatid copepods Oncaea and Corycaeus on 

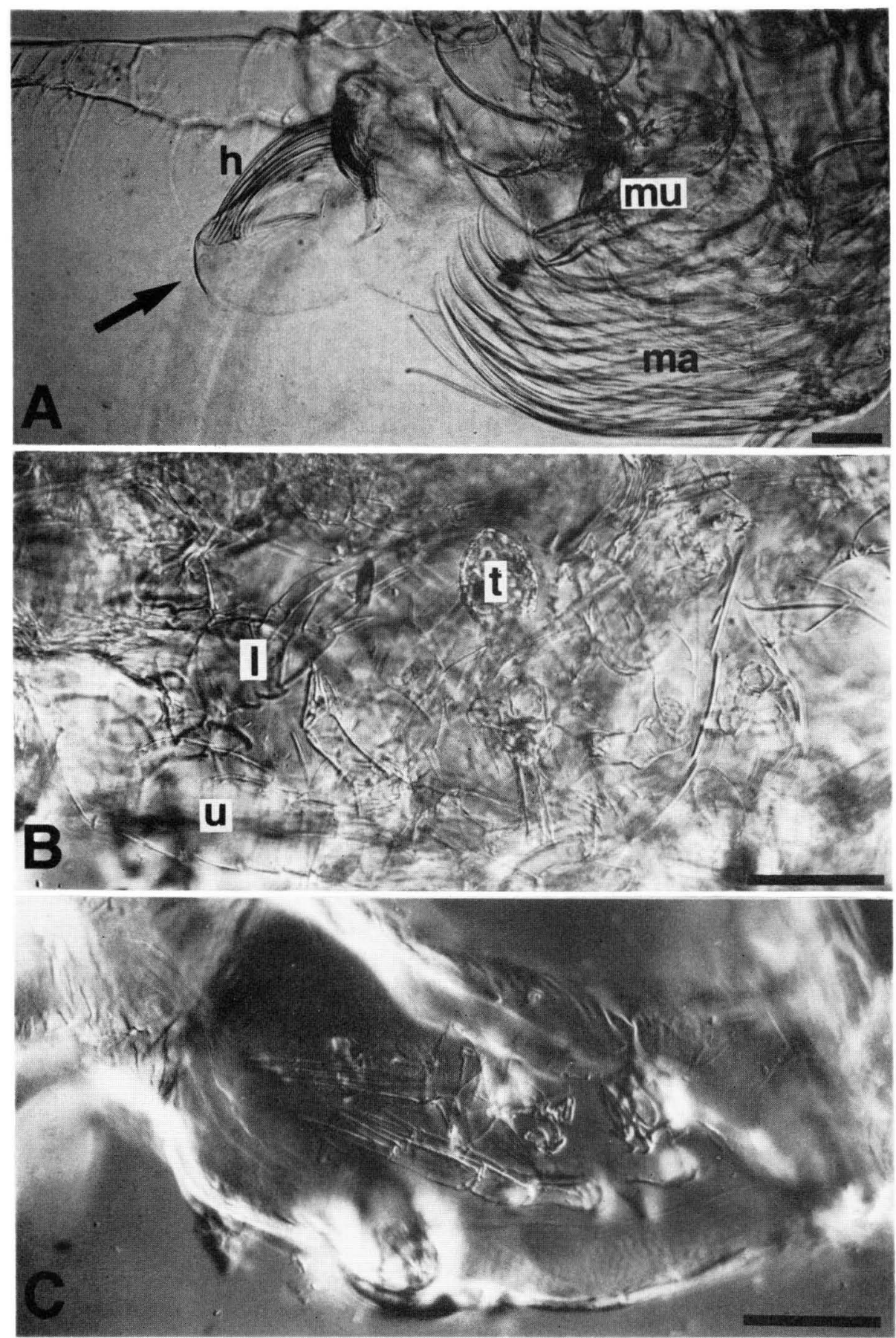

Fig. 2. Food organisms of Pontellopsis yamadae. A. Ingestion of a chaetognath by the copepod (the chaetognath indicated by an arrow; h. hook of the chaetognath; mu. maxillula of the copepod; ma. maxilla of the copepod); B. Food organisms in the digestive tube in prosome of the copepod (t. lorica of a tintinnid; l. leg of Euterpina acutifrons; u. urosome of $E$. acutifrons); C. Legs of $E$. acutifrons in the digestive tube in urosome of the copepod. All scale bars $=0.1 \mathrm{~mm}$. 
Table 1. Food items of the family Pontellidae. (1): Analysis of gut contents or fecal pellets; (2): Laboratory fecding experiments.

\begin{tabular}{|c|c|c|}
\hline Species & Food items & Author \\
\hline $\begin{array}{l}\text { Labidocera acuta } \\
\text { (copepodid V stage) }\end{array}$ & $\begin{array}{l}\text { radiolarian, tintinnid, medusa, copepod } \\
\text { (copepodid \& nauplius), chaetognath, silico- } \\
\text { flagellate, dinoflagellate, diatom }(1) \text {. }\end{array}$ & Ohtsuka (unpublished) \\
\hline L. aestiva & $\begin{array}{l}\text { microcrustacean, diatom (Thalassiosira sp., } \\
\text { Chaetoceros sp.) (1). diatom (Thalassiosira } \\
\text { fluviatilis), Artemia nauplius (2). }\end{array}$ & $\begin{array}{l}\text { Turner (1978) } \\
\text { Anraku \& Omori (1963) }\end{array}$ \\
\hline L. jollae & anchovy larva (2). & Lillelund \& Lasker (1971) \\
\hline L. trispinosa & anchovy larva, Artemia nauplius (2). & Lillelund \& Lasker (1971) \\
\hline L. wollastoni & copepod, diatom (1). & Lebour (1922) \\
\hline Pontella meadii & $\begin{array}{l}\text { copepod, microcrustacean, diatom (Skeleto- } \\
\text { nema costatum, Amphora sp., Navicula sp., } \\
\text { Cymatosira sp., Rhaphoneis sp., Thalassiosira } \\
\text { sp., Thalassionema sp., Chaetoceros sp.) (1). } \\
\text { diatom (Thalassiosira fuviatilis) (2). }\end{array}$ & Turner (1978) \\
\hline Pontellopsis occidentalis & anchovy larva (2). & Lillelund \& Lasker (1971) \\
\hline Anomalocera ornata & $\begin{array}{l}\text { microcrustacean, diatom (Chaetoceros sp., } \\
\text { Skeletonema costatum, Stephanopyxis sp.) (1). } \\
\text { diatom (Thalassiosira fluviatilis) (2). }\end{array}$ & Turner (1978) \\
\hline A. pattersoni & $\begin{array}{l}\text { copepod (Euterpina acutifrons), crustacean, } \\
\text { diatom (Rhizosolenia shrubsolei), Hapto- } \\
\text { phyceae (Phaeocystis) (1). angler larva (2). }\end{array}$ & Lebour $(1922,1925)$ \\
\hline Pontellina morii & copepod (Oncaea etc.) (1). & Fleminger \& Hülsemann (1974) \\
\hline P. platychela & copepod (Oncaea, Paracalanus etc.) (1). & Fleminger \& HüIsemann (1974) \\
\hline P. plumata & copepod (Oncaea etc.) (1). & Fleminger \& Hülsemann (1974) \\
\hline P. sobrina & copepod (Oncaea etc.) (1). & Fleminger \& Hüilsemann (1974) \\
\hline
\end{tabular}

chaetognaths; the latter reported the predation of the calanoid copepod Acartia longiremis (Lilljeborg) on a small chaetognath. Davis (1977) emphasized that this species, which had been considered to be herbivorous or omnivorous, was in fact carnivorous, at least, while the phytoplankters disappeared nearly completely during the long winter night in high latitude $\left(69^{\circ}-70^{\circ} \mathrm{N}\right)$ in northern Norway. These phenomena that some copepods actually feed on predatory chaetognaths which prey on many zooplankers are most important in consideration of the complexity of the marine pelagic food webs. However, it should nerver be overlooked that the mutual relationship between the prey and predator may change with their developmental stages. Nauplius larvae of a copepod, whose copepodids are even carnivorous, become the prey of chaetognaths and, contrary, the carnivorous copepod copepodids may prey on chaetognaths.

\section{References}

Alvariño, A. 1965. Chaetognaths. Oceanogr. Mar. Biol. Ann. Rev., 3: 115-194.

- 1967. The Chaetognatha of the NAGA Expedition (1959-1961) in the South China Sea and the Gulf of Thailand. Part I. Systematics NAGA Report, 4 (2), pp. 197.

Anraku, M., \& M. Omori. 1963. Preliminary survey of the relationship between the feeding habit and the structure of the mouth-parts of marine copepods. Limnol. Oceanogr., 8 (1): 116-126.

Davis, G.G. 1977. Sagitta as food for Acartia. Astarte, 10:1-3. 
Fleminger, A., \& K. Hülsemann. 1974. Systematics and distribution of the four sibling species comprising the genus Pontellina Dana (Copepoda, Calanoida). Fish. Bull., 72: 63-120.

Hattori, H., K. Yuki, Y.P. Zaitsev \& S. Motoda. 1983. A preliminary observation on the neuston in Suruga Bay. La mer, 21: 11-20.

Lebour, M.V. 1922. The food of plankton organisms. J. Mar. Biol. Ass. U.K., 12: 644-677.

1925. Young anglers in captivity and some of their enemies. J. Mar. Biol. Ass. U.K., 13: 721-734.

Lillelund, K., \& R. Lasker. 1971. Laboratory studies of predation by marine copepods on fish larvae. Fish. Bull., 69: 655-667.

Turner, J.T. 1978. Scanning electron microscope investigations of feeding habits and mouthpart structures of three species of copepods of the family Pontellidae. Bull. Mar. Sci., 28: 487-500.

Wickstead, J.H. 1959. A predatory copepod. J. Anim. Ecol., 28: 69-72.

. 1962. Food and feeding in pelagic copepods. Proc. Zool. Soc. London, 139: 545m555. 